Universidad

辛: de Alcalá

BIBLIOTECA

Document downloaded from the institutional repository of the University of Alcala: http://dspace.uah.es/dspace/

This is a postprint version of the following published document:

Fonseca, W., Alice, F. \& Rey-Benayas, E., 2012. Carbon accumulation in aboveground and belowground biomass and soil of different age native forest plantations in the humid tropical lowlands of Costa Rica. New Forests, 43(2), pp.197-211.

Available at https://doi.org/10.1007/s11056-011-9273-9

(C) 2011 Elsevier

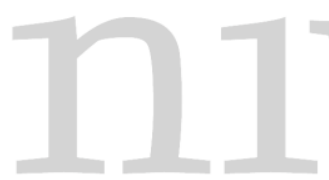

(Article begins on next page)
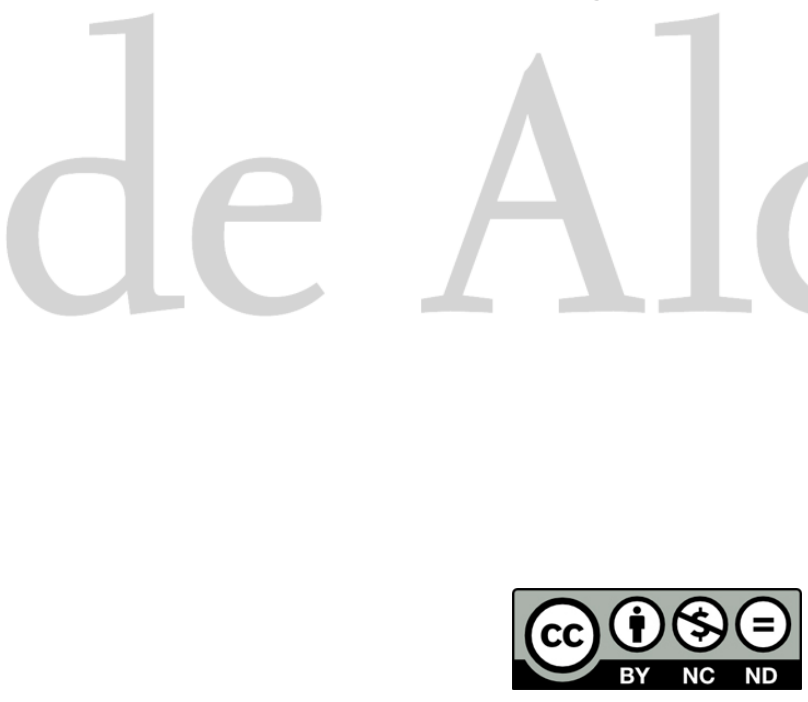

This work is licensed under a

Creative Commons Attribution-NonCommercial-NoDerivatives

4.0 International License. 


\title{
Carbon Accumulation in Aboveground and Belowground Biomass and Soil of Different Age Native Forest Plantations in the Humid Tropical Lowlands of Costa Rica
}

\author{
William Fonseca $^{1,3}$, Federico E. Alice ${ }^{1}$, José María Rey-Benayas ${ }^{2}$ \\ ${ }^{1}$ Escuela de Ciencias Ambientales, Universidad Nacional de Costa Rica, Campus Omar Dengo \\ 86-3000, Heredia, Costa Rica. \\ ${ }^{2}$ Departamento de Ecología, Universidad de Alcalá, Madrid, España. \\ ${ }^{3}$ Corresponding author; e-mail: wfonseca@una.ac.cr
}




\begin{abstract}
Generic or default values to account for biomass and carbon accumulation in tropical forest ecosystems are generally recognized as a major source of errors, making site and species specific data the best way to achieve precise and reliable estimates. The objective of our study was to determine carbon in various components (leaves, branches, stems, structural roots and soil) of single-species plantations of Vochysia guatemalensis and Hieronyma alchorneoides from 0 to 16 years of age. Carbon fraction in the biomass, mean ( \pm standard deviation), for the different pools varied between 38.5 and $49.7 \%( \pm 2.97$ and 21.25). Accumulated carbon in the biomass increased with the plantation age, with mean annual increments of 7.1 and $5.3 \mathrm{Mg} \mathrm{ha}^{-1}$ $\mathrm{yr}^{-1}$ for forest plantations of $V$. guatemalensis and H. alchorneoides, respectively. At all ages, $66.3 \%( \pm 10.6)$ of total biomass was found within the aboveground tree components, while $18.6 \%( \pm 20.86)$ was found in structural roots. The soil $(0-30 \mathrm{~cm})$ contained $62.2( \pm 13.04)$ and $71.5 \%( \pm 17.14)$ of the total carbon (biomass plus soil) under $V$. guatemalensis and $H$. alchorneoides, respectively. Mean annual increment for carbon in the soil was 1.7 and $1.3 \mathrm{Mg}$ $\mathrm{ha}^{-1} \mathrm{yr}^{-1}$ in $V$. guatemalensis and H. alchorneoides. Allometric equations were constructed to estimate total biomass and carbon in the biomass which had an $R^{2}$ aj (adjusted $\mathrm{R}$ square) greater than $94.5 \%$. Finally, we compare our results to those that could have resulted from the use of default values, showing how site and species specific data contribute to the overall goal of improving carbon estimates and providing a more reliable account of the mitigation potential of forestry activities on climate change.
\end{abstract}

Key words: allometric equations; biomass expansion factor; carbon fraction; native tree plantations; soil 


\section{Introduction}

After a long discussion on the contribution of forest ecosystems to the global carbon cycle, it seems as if these will finally be recognized through a Reduced Emissions from Deforestation and Degradation (REDD) mechanism, not only for their ability to absorb anthropogenic carbon but its function as a carbon reservoir. Both these functions have been

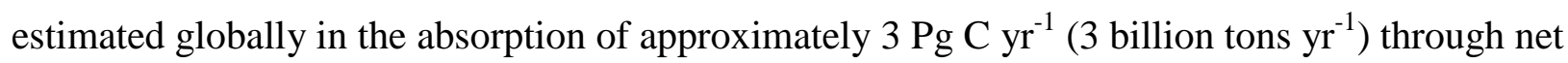
growth (30\% of $\mathrm{CO}_{2}$ emissions from fossil fuel and deforestation) and the storage of an amount of carbon greater than that found in the atmosphere (Canadell and Raupach 2008).

Forest tree plantations have only had a small contribution to the total balance of terrestrial carbon (3.8\% or 140 million ha of the world's total forest area; FAO 2006) but their potential to absorb and store carbon has been recognized to play a more important role in the future mitigation of climate change (Canadell et al. 2007). Besides, if forestry plantations are designed as elements within broader land management plans, they could be compatible with adaptation measures (Canadell et al. 2004, IPCC 2007, Paquette and Messier 2010) while overcoming some of the shortcomings discussed on some of the social and environmental benefits associated to these type of ecosystems (Bodegom et al. 2008, Paquette and Messier 2010), specially through native forest tree plantations (Montagnini et al. 2003, Jackson et al. 2005, Turner et al. 2005, Bodegom et al. 2008). However, scientific information that allows for the precise assessment of all these benefits and therefore the development of adequate policies is far from being complete (IPCC 2007, Nabuurs et al. 2007).

Many authors agree on the weaknesses from current estimates on the absorption and storage capacity of forest ecosystems (Elias and Potvin 2003, Chave et al. 2004, Sarmiento et al. 2005) and the implications these have on the development of climate change related policies (Ito 
et al. 2008, Somogyi et al. 2008). Such is the case of a future REDD mechanism or any other results-based payment scheme. In order to have a just distribution on the costs and benefits from these type of schemes, local, national or regional monitoring, reporting and verification systems with a higher degree of confidence in the estimates on the changes in carbon stocks is required (UNFCCC 2010). This leads to the need for site and species specific data, since the interactions between environmental and anthropogenic factors that cause variations in the carbon concentrations within the biomass (with global variations ranging from 1 to $35 \mathrm{t} \mathrm{CO}_{2} \mathrm{ha}^{-1} \mathrm{yr}^{-1}$; IPCC 2007) (Sarmiento et al. 2005, Keith et al. 2009) are not being reflected under current estimates. These, are in most cases, currently performed using generic values on the amounts of biomass, carbon in the biomass or generic allometric equations to determine biomass and carbon for a given forest ecosystem.

Attempting to make a small but important contribution to the understanding of tropical forest ecosystems and as a means towards more precise and reliable estimates, this work provides exhaustive information for two native tree species (V. guatemalensis and $H$. alchorneoides) under forest plantations in humid tropical ecosystems in the Costa Rican Caribbean Region. These species were selected since they are the most promising native species in terms of productivity (Montero and Montagnini 2006, Piotto et al. 2010, Redondo 2007) and therefore the most commonly planted in the region. These have been used for construction or, in the case of $V$. guatemalensis, as wood pallets for shipping. Due to the combination of these factors, there has been an important advance in terms of the knowledge on these species including genetic improvement programs to improve their productivity and wood quality (Solís and Moya 2004ab, Montero et al 2007). 
While trying to increase the precision and reliability of carbon estimates at a regional scale, we would also expect that the availability of such information might increase the consideration of the mitigation potential of these activities into forest policymaking. The objectives for this work were (1) to estimate the amount of accumulated biomass and carbon captured by single-species forestry plantations of two native species, at different ages, as well as its distribution in the different pools (biomass and soil); (2) to determine the biomass expansion factor for both species; (3) to determine the carbon fraction in the biomass for all the different components; and (4) to develop biomass models based on allometric relations to estimate biomass and carbon at the tree and ecosystem level.

\section{Materials and methods}

\subsection{Study site and sample size}

This study was conducted in the Costa Rican Caribbean region, corresponding to the very humid tropical forest life zone (Holdridge 1967). The altitude varies between 50 and $350 \mathrm{~m}$ asl. The climate is humid to very humid, hot to very hot, with or without a dry season of less than 25 intermittent days with water deficit per year (Herrera 1985, Mena 2009). The mean annual precipitation varies between 3420 and $6840 \mathrm{~mm}$ and mean annual temperature between 25 and $27^{\circ} \mathrm{C}$. Soils are Ultisols, with less than $35 \%$ base saturation, deep, well drained, red or yellow in color and with a relatively low fertility (ITCR 2004).

A total of nine sites with forest plantations of $H$. alchorneoides and $V$. guatemalensis established in local farmers lands, were selected. In general terms, these plantations were established in lands where the previous land use was abandoned pastures, with relatively compacted soils and medium fertility. Distance between trees when planting took place was $3 \times 3$ for both species, although when sampling units were established, these plantations showed 
different distances due to age and management practices such as clearing and thinning. In each plantation of a given age, between one to eight sampling plots were established depending on the size of the plantation. The sampling units were rectangular with an area of $500 \mathrm{~m}^{2}$. A total of 58 sampling plots were established in forest plantations of $H$. alchorneoides and 54 in $V$. guatemalensis. Plantation ages ranged from 0.5 to 16 years.

\subsection{Biomass estimation}

The estimates for the biomass and stored carbon followed the methods proposed by MacDicken (1997) with some modifications. A nested plot design was used, measuring the various biomass components (trees, herbs and necromass) in different sized subplots. For each of the biomass components that are described below, an approximately one kg field sub-sample was taken to the laboratory for analyses.

Aboveground tree biomass -In each $500 \mathrm{~m}^{2}$ sampling plot, diameter at breast height (dbh) was measured for every tree and the tree with average dbh was selected and harvested for biomass measurements. A total of 54 trees with diameters between 0.5 and $40.5 \mathrm{~cm}$ were harvested in $V$. guatemalensis and 58 for $H$. alchorneoides with diameters between 0.5 and 28.8 $\mathrm{cm}$. To quantify biomass, a direct destructive sampling method was used, separating leaves, branches, stem and root components. For trees that due to their size represented an income for the plantation owner, to calculate their biomass we determined merchantable volume through the formula by Smalian (Prodan et al.1997) and used the reported wood specific weight (Carpio 1995, CATIE 2003).

Belowground tree biomass - Belowground biomass refers exclusively to structural or coarse roots (and all of the fine roots attached to the main root after harvesting) from planted trees. Excavation and extraction was carried out with a retro-excavator or trencher, agricultural 
tractor and/or manually with a chain hoist. These roots were then washed in the field and weighed once they were air dry for one - two hrs.

Biomass in herbaceous vegetation, small woody material and seedlings - Grasses, lianas, ferns, shrubs and some tree seedlings from natural regeneration with a dbh $<2.5 \mathrm{~cm}$, were measured in $1 \times 1 \mathrm{~m}$ subplots located in every corner of the main $500 \mathrm{~m}^{2}$ plot. In each $1 \mathrm{~m}^{2}$ subplot all plant material was harvested to ground level and weighed in the field.

Necromass - Necromass or dead woody material found at ground level was divided into fine necromass (litter and woody material $<2 \mathrm{~cm}$ in diameter) and large necromass (dead woody material $\geq 2 \mathrm{~cm}$ in diameter). Fine necromass was estimated from four $0.5 \times 0.5 \mathrm{~m}$ subplots (grouping these 4 subplots into one sample for analysis), while large necromass was evaluated from one 5 x $5 \mathrm{~m}$ subplot, all distributed randomly throughout the $500 \mathrm{~m}^{2}$ plot. The collected material was then weighed in the field.

\subsection{Soil organic carbon}

The amount of carbon stored per hectare was obtained considering soil depth $(\mathrm{cm})$, bulk

density $\left(\mathrm{g} \mathrm{cm}^{-2}\right)$ and the percentage of soil organic carbon content (SOC). The sampling depth to determine carbon content was $30 \mathrm{~cm}$, based on findings that support that as much as $60 \%$ of stored carbon has been found at this depth (Russell et al. 2007, Schedlbauer and Kavanagh 2008) and that at lower depths, stored carbon tends more stable (Sombroek et al. 1993) since the soil is less altered by mechanization practices or by changes in forest cover. Bulk density was determined through the cylinder method (MacDicken 1997), collecting one cylinder per plot. To determine SOC, a total of four soil samples were randomly selected within the main plot, extracted and mixed together in order to obtain a sample of approximately $1 \mathrm{~kg}$. Sampling size were 58 for H. alchorneoides and 54 for $V$. guatemalensis. 


\subsection{Carbon fraction analysis in plant material and soil}

Each sub-sample of the different components of the biomass was taken to the lab and dried in an oven at $60^{\circ} \mathrm{C}$ for 72 hours to estimate its dry matter content (DMC). Soil samples were dried at $55^{\circ} \mathrm{C}$ for three days and subsequently ground and run through a $240-\mu \mathrm{m}$ sieve.

Carbon content in the plant biomass and soil was determined following the methods by Pregl and Dumas (Bremner and Mulvaney 1982) in an auto-analyzer (Perkin-Elmer series II, CHN/S 2400, Norway Co.).

\subsection{Biomass expansion factor (BEF)}

The biomass expansion factor is used to expand from a certain amount of tree volume or biomass, which includes some, but not all tree compartments, to another one that includes more or all tree compartments (Somogyi et al. 2008). In this case is the ratio between total aboveground biomass and stem, to be applied to transform stem volume into total aboveground biomass (Loguercio and Defoseé 2001, Segura and Kanninen 2002, Dauber et al. 2008).

\subsection{Biomass allometric models selection}

The models were adjusted using the method of ordinary least squares. Methods presented by Salas (2002) and Segura and Andrade (2008) were followed to determine the best fit equation. 2.7 Mean annual increment (MAI)

This was expressed on the basis of both biomass (B) and carbon (C) per number of years (t), B/t and C/t, in Mg/ha (Prodan et al. 1997).

\section{Results}

\subsection{Biomass and carbon accumulation}

At ages 0.5 , when most of the biomass was herbaceous vegetation, the amount of carbon in the total biomass was 1.1 and $0.9 \mathrm{Mg} \mathrm{ha}^{-1}$ in $V$. guatemalensis and H. alchorneoides 

alchorneoides, by 16 years of age (Table 1). Averaged across 16 years, the MAI for total biomass and carbon in the total biomass were 14.5 and $7.1 \mathrm{Mg} \mathrm{ha}^{-1}$ for $V$. guatemalensis and 10.0 and 5.3 $\mathrm{Mg} \mathrm{ha}^{-1}$ for $H$. alchorneoides. For carbon in the aboveground tree biomass, these were 4.2 and 3.0 $\mathrm{Mg} \mathrm{ha}^{-1} \mathrm{yr}^{-1}$ for $V$. guatemalensis and H. alchorneoides, respectively. There was a positive correlation between carbon in the biomass and age for $V$. guatemalensis $(\mathrm{r}=0.79$, $P<0.01, n=56)$ and for $H$. alchorneoides $(\mathrm{r}=0.63, P<0.01, n=61)$.

From the total tree biomass, stems of $V$. guatemalensis and H. alchorneoides represent 62.0 and $55.6 \%$ respectively, followed by coarse roots (22.6 and $22.8 \%$, respectively) and branches (11.7 and $17.5 \%$, respectively). Leaves represented just a marginal proportion from total tree carbon (Table 1). At an ecosystem level (total biomass) for both species, trees account for approximately $85 \%$, while necromass (large and fine) contains about $12.5 \%$. There was a negative correlation between the ratio of aboveground and belowground biomass related to plantation age $(r=-0.39, P=0.01, n=53$ for $V$. guatemalensis and $r=-0.32, P=0.05, n=58$ for H. alchorneoides).

Carbon accumulated in the soil (at $30 \mathrm{~cm}$ depth) in the period from 0.5 to 16 years of age went from 85.8 to $107.0 \mathrm{Mg} \mathrm{ha}^{-1}$ in $V$. guatemalensis ( \pm 46.5 and 14.1) and 77.2 to $101.8 \mathrm{Mg} \mathrm{ha}^{-1}$ ( \pm 45.0 and 21.8) in H. alchorneoides. The average for all MAI values for the different ages in the carbon found at the soil was 1.7 and $1.3 \mathrm{Mg} \mathrm{ha}^{-1} \mathrm{yr}^{-1}$ respectively. Changes observed for carbon in the soil were statistically significant and the correlation between soil carbon and plantations age was positive but low $(r=0.38, P=0.01, n=56$ for $V$. guatemalensis and $r=$ 0.36, $P=0.01, n=61$ for $H$. alchorneoides). 
The amount of total carbon (biomass and soil) went from $88.7 \mathrm{Mg} \mathrm{ha}^{-1}$ at early ages (when $98.9 \%$ is soil carbon) to $204.3 \mathrm{Mg} \mathrm{ha}^{-1}$ at 16 years (when $52.4 \%$ is soil carbon) in $V$. guatemalensis forest plantations. For H. alchorneoides these results were $79.4 \mathrm{Mg} \mathrm{ha}^{-1}$ in recently established plantations (when $99.7 \%$ is soil carbon) and $180.48 \mathrm{Mg} \mathrm{ha}^{-1}$ at 16 years (when $56.4 \%$ is soil carbon). Soil carbon had a negative correlation with the age of the stand $(r=$ $-0.68, P<0.01, n=56$ for $V$. guatemalensis and $r=-0.62, P<0.01, n=61$ for $H$.

alchorneoides). The total amount of carbon stored in the soil averaged 62.2 and $71.5 \%$ in $\mathrm{V}$. guatemalensis and H. alchorneoides, respectively, with average MAI for total carbon of each of the different ages evaluated in forest plantations of $V$. guatemalensis of $8.7 \mathrm{Mg} \mathrm{C}^{-1}$ and 6.5 $\mathrm{Mg} \mathrm{C} \mathrm{ha}{ }^{-1}$ in H. alchorneoides.

\subsection{Carbon fraction in the biomass}

The carbon fraction for the more lignified biomass components (stem, branches, roots and large necromass) in plantations of 0.5 to 16years, varied between $46.5( \pm 4.7)$ and $48.6 \%( \pm 3.7)$ in V. guatemalensis tree plantations and between $47( \pm 9.9)$ and $49.7 \%( \pm 3.8)$ in $H$. alchorneoides (Table 2). The carbon fraction for leaves, herbaceous vegetation and fine necromass (litter) from these plantations varied between $38.5( \pm 2.9)$ and $44.6 \%( \pm 3.3)$ in $V$. guatemalensis and between $42.8( \pm 9.1)$ and $45.9 \%( \pm 4.7)$ in $H$. alchorneoides. The standard deviations were below five, except for branches, herbaceous vegetation and fine necromass of $H$. alchorneoides (Table 2).

\subsection{Biomass expansion factor (BEF)}

The BEF for $V$. guatemalensis was $1.56( \pm 0.72)$ and $1.57( \pm 0.42)$ for H. alchorneiodes. 


\subsection{Allometric models for the estimation of biomass and carbon}

The selected allometric models to estimate total biomass and carbon in plant material (planted trees, herbaceous vegetation and necromass) resulted in adjusted $R^{2}$ greater than $94.5 \%$; all models were significant $(P<0.01)$, had low standard errors (Table 3 ) and showed a normal distribution. The models with the better adjustment express the logarithmic transformation of the dependent variable as a square root function of the basal area.

\section{Discussion}

\subsection{Carbon accumulation in forest tree plantations}

Despite differences in methodologies and environmental conditions, other tree plantations in Costa Rica have reported similar C accumulation rates to those obtained through this study (4.2 $\mathrm{Mg} \mathrm{ha}^{-1} \mathrm{yr}^{-1}$ in V. guatemalensis and $3.0 \mathrm{Mg} \mathrm{ha}^{-1} \mathrm{yr}^{-1}$ in H. alchorneoides). For native species such as Bombacopsis quinata, Terminalia amazonia, V. guatemalensis, Dipteryx panamensis, $H$. alchorneoides and Virola koschnyi results have been reported between $1.7-7 \mathrm{Mg} \mathrm{ha}^{-1} \mathrm{yr}^{-1}$ (Cubero and Rojas1999, Montero and Kanninen 2002, Pérez and Kanninen 2003, Redondo and Montagnini 2006, Redondo 2007). In exotic tree species, Tectona grandis and Gmelina arborea, reported results are in the range of $2.0-6.7 \mathrm{Mg} \mathrm{ha}^{-1} \mathrm{yr}^{-1}$ (Cubero and Rojas1999, Subak 2000, Pérez and Kanninen 2003). However, these estimates do not take into account components such as roots, herbaceous vegetation or necromass, which, as shown by our results, cause significant increases in MAI (7.1 Mg ha ${ }^{-1} \mathrm{yr}^{-1}$ for V. guatemalensis and 5.3 $\mathrm{Mg} \mathrm{ha}^{-1} \mathrm{yr}^{-1}$ in H. alchorneoides).

In this study, the differences in biomass and carbon accumulation between both species were largely due to differences in their growth rates (Redondo 2007). $V$. guatemalensis has a fast growth rate and a short rotation period close to 15 years (Petit and Montagnini 2004, Solís and 
Moya 2004b), while H. alchorneoides has a lower growth rate and rotation periods between 25 and 40 years (Solís and Moya 2004a, Montero et al. 2007).

Annual carbon accumulation rates in the soil from this study, $1.7 \mathrm{Mg} \mathrm{ha}^{-1}$ in forest plantations of $V$. guatemalensis and $1.3 \mathrm{Mg} \mathrm{ha}^{-1}$ in H. alchorneoides, are above MAI values of $0.66 \mathrm{Mg} \mathrm{ha}^{-1}$ in forestry plantations (Russell et al. 2007) and similar to 1.9 for secondary forests in Ecuador (Rhoades et al. 2000). However, SOC estimates in tropical forest ecosystems, where carbon content is highly variable according to spatial distribution, makes comparisons as well as precise measurements and extrapolations quite difficult (Mendoza et al. 2003, Bauhus et al. 2005, Jandl 2006).

Although most studies agree that the soil is the most important carbon pool in forest ecosystems (Russell et al. 2007, Schedlbauer and Kavanagh 2008, Tschakert et al. 2007), changes in carbon stocks within this pool are not easy to assess. Changes observed were statistically significant, although the positive but low correlation between soil carbon and age, suggests a low enhancement of soil carbon due to forest tree plantations. These results could be explained due to the young age of the studied plantations and the slow carbon incorporation to the soils reported by other studies (Singh et al. 2007, Gamboa et al. 2008). However, previous land use might be also playing an important role. Guo and Gifford (2002) cited by the IPCC (2007) report that sites with low initial soil carbon stocks such as those after prolonged cultivations, increase carbon content after reforestation, while it might decrease after reforestation occurs on sites with high soil carbon contents such as grasslands. Although some studies agree with these losses, these have been reported to recover after several years (Gaboury et al. 2009, Tan et al. 2009). Similar to our results, significant net changes after the transition from pasture lands to secondary forests have been reported (Veldkamp et al. 2003, Powers and 
Veldkamp 2005, Schedlbauer and Kavanagh 2008) but in different age forest fallows, other studies have failed to find significant differences among different age groups (Tschakert et al. 2007). All these results reveal that there is not a common trend, or at least not one that can be easily discerned from our results, and that most probably carbon accumulation in the soil responds to a combination of circumstances that include everything from previous land use, site specific conditions (Schöning et al. 2006) and the land cover being evaluated. Therefore, identifying consistent changes in the carbon stock from soils seems to require site specific measurement and extrapolations should be avoided.

\subsection{Biomass carbon fraction}

A carbon fraction of 0.5 has been recognized as an acceptable average, therefore being the most common conversion factor used (Hoen and Solberg 1994, Husch 2001, Losi et al. 2003, Sarmiento et al. 2005, Montero and Montagnini 2006, Redondo 2007). However, studies have also shown that the use of carbon fractions in the range of 0.45 and 0.50 might account for as much as a $10 \%$ difference when applied to the same site and the same set of data (Elias and Potvin 2003). Based on our biomass data and comparing both the obtained carbon fraction and the lower end value from the accepted range (0.45), we determined underestimations in total tree biomass between 4 and $6 \%$ depending on specie due to the use of 0.45 .

Overestimations are still more common when considering components less lignified such as fine necromass, tree leaves and herbaceous vegetation. For these, as results from this study show and which are supported by Gifford (2000), Gayoso and Guerra (2005) and Sarmiento et al. (2005), carbon fractions are in the range of 0.40 and 0.45 . Therefore, extrapolating on the assumption that all plant biomass has a constant carbon fraction will only lead to increased errors. 


\subsection{Biomass expansion factor (BEF)}

BEF determined for both species in this study (1.56) is within the lower end of the range reported for different species in tropical natural forests and forest plantations $(1.5-2.88)$ (Soliz 1998, Segura et al. 2000, Arrega 2002, Montero and Kanninen 2002, Dauber et al. 2008, Fonseca et al. 2009). Using a 1.75 BEF recommended by Brown and Lugo (1989) and cited by Chacón et al. (2009) as an appropriate average used in the Costa Rican National Greenhouse Gas Inventory, we estimated an average of $29 \%$ more carbon when applied to our total tree biomass data (27.7 and 20.8 $\mathrm{Mg} \mathrm{C} \mathrm{ha}^{-1}$ for $V$. guatemalensis and H. alchorneoides, respectively).

\subsection{Carbon distribution in the biomass compartments}

In this study, with the exemption of herbaceous vegetation and necromass, the compartments that account for the greatest amount of carbon in the ecosystem were estimated with acceptable sampling errors (between 10 and 15\% which are within the levels proposed by MacDicken 1997).

The fact that the stem accounts for the largest amount of carbon from total tree biomass has been largely documented, with ranges going from 50 to $92 \%$ for different species from forest plantations (Gutiérrez and Lopera 2001, Pérez and Kanninen 2003, Redondo 2007, Redondo and Montagnini 2006). Although our results are within this range (62\% and 55.6\% for $V$. guatemalensis and $H$. alchorneoides respectively), these are found within the lower end of the reported range considering that we included coarse roots in our estimations.

Coarse roots accumulate the largest amount of belowground carbon but are almost unknown for most tropical tree species (MacDicken 1997, Sarmiento et al. 2005). When using the average percentage of coarse roots in total tree biomass for both species estimated in this study (22\%), an increase of $18.8 \mathrm{Mg} \mathrm{C} \mathrm{ha}^{-1}$ would be obtained if compared to the $10-15 \%$ 
recommended by MacDiken (1997) as a conservative estimate. This result agrees with Sarmiento et al. (2005), who state that most estimates from this component are most probably underestimations.

At an ecosystem level, necromass and herbaceous vegetation are also usually neglected in most studies (Chave et al. 2004, Sarmiento et al. 2005). These represented in our study almost $15 \%$ from the total carbon in the biomass, evidencing the importance of such pools for carbon accounting. These pools also play an important role for their contribution to soil fertility and degraded land restoration processes (Fisher 1995, Montagnini and Mendelsohn 1997, Montagnini 2000).

\subsection{Allometric models}

The selection of the equation to be used for the estimation of biomass and carbon has been regarded as the most important source of error (Chave et al. 2004, Návar 2009), with overestimations as high as $100 \%$ due to the use of generic equations (van Noordwijk et al. 2002). Common errors when selecting an equation occur when using these for zones different from those where it was developed (Buvaneswaran et al. 2006) or for diameter ranges outside the one used in their construction (Losi et al. 2003, Chave et al. 2004, Sarmiento et al. 2005). These same authors mention that when constructing an equation, weaknesses are usually related to a small sample size and failing to take into account wood specific gravity.

Published allometric models for individual tropical trees (Pérez and Kanninen 2002, Montero and Montagnini 2006, Návar 2009), rarely include the amount of carbon corresponding to coarse roots or the amount of biomass and carbon per hectare from other biomass compartments. The presented models were developed including all compartments, based 
on a large set of samples $(n>50)$ and in the case of tree biomass, on a large range of diameters and ages, and achieving a good prediction capacity (> 94.5\% in all cases).

\section{Conclusions}

Carbon in the biomass was over $78 \mathrm{Mg} / \mathrm{ha}$ but the soil represents the main carbon sink at an ecosystem level with more than $85 \mathrm{Mg} / \mathrm{ha}$. Mean annual increments for carbon in the biomass was above $5.3 \mathrm{Mg} / \mathrm{ha}$ and over $1.3 \mathrm{Mg} / \mathrm{ha}$ in the soil. The stem represents the most important component from tree biomass with carbon MAI values above $3 \mathrm{Mg} / \mathrm{ha}$.

Considering that the development of local biomass equations is a resource expensive operation, models that allow per hectare quantification of biomass and carbon using simple field estimation variables such as basal area represents an important advantage towards the precise and reliable quantification of carbon accumulation in these plantations. However, we agree with most authors, in cautioning that the use of these equations should be preceded by a thorough review of their applicability to the studied community in order to avoid over or underestimations.

\section{Acknowledgements}

The authors would like to express their sincere gratitude to Johan Montero and Henry Toruño, researchers at the Forestry Research and Services Institute from the National University of Costa Rica, for their support during field data collection. This work received finance from the National University of Costa Rica, the Costa Rican Ministry of Science and Technology and from the private sector.

\section{Literature cited}

Arreaga W (2002) Almacenamiento de carbono en bosques con manejo forestal en la Reserva de la Biosfera Maya, Petén, Guatemala. Tesis Mag. Sc. CATIE, Turrialba, CR. 86 p. 

Bauhus J, Khanna P K, Hopman P, Ludwing B, Weston C (2005) Evaluation of soil organic matter as a meaningful indicator of important soil properties and processes in native forest ecosystems. Australian Government. Forest and Wood Products. Research and Development Corporation. Project No. PN99.803. 53 p. http://www.fwpa.com.au/Resources/RD/WAPIS/PN99.803.pdf

Bodegom A van, Berg Y van den, Meer P van der (2008) Forest plantations for sustainable production in the tropics. Wageningen University and Research Centre, The Netherlands. ISBN 978-90-8585-231-5. http://www.cdic.wur.nl/NR/rdonlyres/DFDA8928-9664-4EF3A593-C5E3023D3164/68149/Rapport_Forestplantations_totaal_lowres_sec.pdf

Bremner JM, Mulvaney C (1982) Carbon, inorganic nitrogen. In R. Miller and D. Keeney (eds.). Methods for soil analysis: chemical and microbiological properties, pp 552, 673-682. 2 ed. American Society of Agronomy, Madison, US.

Buvaneswaran C, George M, Pérez D, Kanninen M (2006) Biomass of Teak Plantations in Tamil Nadu, India and Costa Rica Compared. J. Trop. For. Sci. 18(3): 195-197.

Canadell J, Ciais P, Cox P, Heimann M (2004) Quantifying Terrestrial Carbon Sinks. Climatic Change 67: 145-146.

Canadell JG, Kirschbaum MUF, Kurz WA, Sanz MJ, Schlamadinger B, Yamagata Y (2007) Factoring out natural and indirect human effects on terrestrial carbon sources and sinks. Environmental Science \& Policy 10: 370 - 384.

Canadell JG, Raupach MR (2008) Managing Forests for Climate Change Mitigation. Science 320: 1456.

Carpio I (1995) Maderas de Costa Rica: 150 especies comerciales. Ed. Universidad de Costa Rica. 2 ed. San José, Costa Rica. 338 p. 
CATIE (2003) Árboles de Centroamérica: un manual para extensionistas. J Cordero y DH Boshier (ed.). Turrialba, Costa Rica. CATIE. 1079 p.

Chacón AR, Montenegro J, Sasa J (2009) Inventario Nacional de Gases con Efecto Invernadero y Absorción de Carbono en Costa Rica en el 2000 y 2005. Gobierno de Costa Rica, Ministerio del Ambiente, Energía y Telecomunicaciones, Instituto Meteorológico Nacional. 78 p. http://cglobal.imn.ac.cr/Pdf/gases/Inventario\%20Gases\%20Efecto\%20Invernadero.pdf

Chave J, Condit R, Aguilar S, Hernandez A, Lao S, Perez R (2004) Error propagation and scaling for tropical forest biomass estimates. Phil. Trans. R. Soc. Lond. B 359: 409-420. $\underline{\text { http://si- }}$ pddr.si.edu/dspace/bitstream/10088/6729/1/Chave_Condit_Aguilar_Hernandez_Lao_and Perez_2004.pdf

Cubero J, Rojas S (1999) Fijación de carbono en plantaciones de Gmelina arborea, Tectona grandis y Bombacopsis quinata. Tesis de Licenciatura. Heredia, Costa Rica, Universidad Nacional, Escuela de Ciencias Ambientales. 94 p. http://cglobal.imn.ac.cr/Pdf/mitigacion/Estudio\%20sobre\%20Fijacion\%20de\%20Carbono \%20en\%20Plantaciones.pdf

Dauber E, Terán J, Guzmán R (2008) Estimaciones de biomasa y carbono en bosques naturales de Bolivia. Revista Forestal Iberoamericana 1(1):1-10. http://www.revforiberoamericana.ula.ve/archivos/DOC2.pdf

Elias M, Potvin C (2003) Assessing inter- and intra-specific variation in trunk carbon concentration for 32 neotropical tree species. Can. J. For. Res. 33: 1039-1045. 
FAO ( 2006) Global Forest Resource Assessments 2005: Progress towards sustainable forest management. FAO Forestry Paper N 146. http://www.fao.org/documents/show_cdr.asp?url_file=/docrep/008/a0400e/a0400e00.htm

Fisher RF (1995) Amelioration of degraded rain forest soils by plantations of native trees. Soil Sci. Soc. Am. J. 59:544-549.

Fonseca W, Alice F, Rey-Benayas JM (2009) Modelos para estimar la biomasa de especies nativas en plantaciones y bosques secundarios en la zona Caribe de Costa Rica. Bosque 30: $36-47$.

Gaboury S, Boucher JF, Villeneuve C, Lord D, Gagnon R (2009) Estimating the net carbon balance of boreal open woodland afforestation: A case-study in Quebec's closed-crown boreal forest. For. Ecol. Manage. 257: 483-494.

Gamboa A, Hidalgo C, de León F, Etchevers J, Gallardo J, Campo J (2008) Nutrient addition differentially affects soil carbon sequestration in secondary Tropical dry forests: Earlyversus late-succession stages. Restor. Ecol. 18 (2): 252 - 260. http://www3.interscience.wiley.com/journal/121356707/abstract

Gayoso J and Guerra J (2005) Contenido de carbono en la biomasa aérea de bosques nativos en Chile. Bosque 26: 33-38.

Gifford R (2000) Carbon contents of above-ground tissues of forest and woodland trees.

Canberra: Australian Greenhouse Office, National Carbon Accounting System, Technical. Report No. 22. 17 p.

Guo LB and Gifford RM (2002) Soil carbon stocks and land use change: a meta analysis. Global Change Biology 8: 345-360. 
Gutiérrez VH and Lopera J (2001) Metodología para la cuantificación de existencias y flujo de carbono en plantaciones forestales. Valdivia, Chile. Simposio Internacional Medición y Monitoreo de la Captura de Carbono en Ecosistemas Forestales, 18 al 20 de octubre del 2001. 17 p. http://www.uach.cl/procarbono/pdf/simposio_carbono/15_Gutierrez.PDF

Herrera W (1985) Clima de Costa Rica: Vegetación y Clima de Costa Rica. Volumen 2. Gómez LD (ed.). San José, Costa Rica. UNED. 118 p.

Hoen H, Solberg B (1994) Potential and economic efficiency of carbon sequestration in forest biomass through silvicultural management. Forest Sci. 40: 429-451.

Holdridge L (1967) Life Zone Ecology. San José, Costa Rica. Centro Científico Tropical. 82 p. Husch B (2001) Estimación del contenido de carbono en los bosques. Valdivia, Chile. Simposio Internacional Medición y Monitoreo de la Captura de Carbono en Ecosistemas Forestales, 18 al 20 de octubre del 2001.9 p. http://www.uach.cl/simposiocarbono/doc/Husch.PDF IPCC (2007) Climate Change 2007: Mitigation of Climate Change. Contribution of Working Group III to the Fourth Assessment Report of the Intergovernmental Panel on Climate Change [B Metz, OR Davidson, PR Bosch, R Dave, LA Meyer (eds)], Cambridge University Press, Cambridge, United Kingdom and New York, NY, USA., 851 pp. ITCR (2004) Atlas digital de Costa Rica. Laboratorio de Sistemas de Información Geográfica, Escuela de Ingeniería Forestal. Cartago, CR.

Ito A, Penner JE, Prather MJ, de Campos CP, Houghton RA, Kato T, Jain AK, Yang X, Hurtt GC, Frolking S, Fearon MG, Chini LP, Wang A, Price DT (2008) Can we reconcile differences in estimates of carbon fluxes from land-use change and forestry for the 1990s? Atmos. Chem. Phys. 8: 3291-3310. www.atmos-chem-phys.net/8/3291/2008/ 
Jackson R, Jobba E, Avissar R, Somnath R, Barrett D, Cook CH, Farley K, Le Maitre D, McCarl B, Murray B (2005) Trading water for carbon with biological carbon sequestration. Science 310: 1944-1947.

Jandl R (2006) Secuestro de carbono en bosques: el papel del suelo. Taller internacional sobre secuestro de carbono. IUFRO-RIFALC. 9 p.

Keith H, Mackey BG, Lindenmayer DB (2009) Re-evaluation of forest biomass carbon stocks and lessons from the world's most carbon-dense forests. PNAS. 106 (28): 11635-11640. http://www.pnas.org/content/106/28/11635.short.

Loguercio G, Defossé G (2001) Ecuaciones de biomasa aérea, factores de expansión y de reducción de la lenga Nothofagus pumilio (Poepp. et Endl) Krasser, en el So del Chubut, Argentina. In Simposio Internacional Medición y Monitoreo de la Captura de Carbono en Ecosistemas Forestales. Valdivia, Chile. 18 al 20 de octubre de 2001. 11 p.

Losi CJ, Siccama TG, Condit R, Morales JE (2003) Analysis of alternative methods for estimating carbon stock in young tropical plantations. For. Ecol. Manage 184: 355-368.

MacDicken K (1997) A guide to monitoring carbon storage in forestry and agroforestry projects. Forest carbon Monitoring Program. Winrock International Institute for Agricultural Development (WRI). http://www.winrock.org/REEP/PUBSS.html

Mena M (2009) Clima de Costa Rica. Vertiente del Caribe. Instituto Meteorológico Nacional. http://www.imn.ac.cr/educacion/climacr/vertient_caribe.html

Mendoza J, Karltun E, Olsson M (2003) Estimations of amounts of soil organic carbon and fine root carbon in land use and land cover classes, and soil types of Chiapas highlands, Mexico. For. Ecol. Manage. 177: 191-206. 
Montagnini F, Mendelsohn RO (1997) Managing Forest Fallows: Improving the Economics of Sweden Agriculture. Royal Swedish Academy of Sciences. Ambio Vol. 26 No.2, March 1997 p. 118-123

Montagnini F (2000) Accumulation in above-ground biomass and soil storage of mineral nutrients in pure and mixed plantations in a humid tropical lowland. For. Ecol. Manage. 134: $257-270$

Montagnini F, Kanninen M, Montero M, Alice F (2003) Sostenibilidad de las plantaciones forestales: Ciclaje de nutrientes y efectos de la especies sobre la fertilidad de los suelos. 13 p. http://www.una.ac.cr/inis/docs/suelos/Florencia.pdf.

Montero M, Kanninen M (2002) Biomasa y Carbono en plantaciones de Terminalia amazonia (Gmel.) Excell en la zona Sur de Costa Rica. Revista Forestal Centroamericana. 3940:50-55.

Montero M, Montagnini F (2006) Modelos alométricos para la estimación de biomasa de diez especies nativas en plantaciones en la región Atlántica de Costa Rica. Recursos Naturales y Ambiente 45:118-125.

Montero M, de los Santos H, Kanninen M (2007) Hieronyma alchorneoides: Ecología y silvicultura en Costa Rica. Turrialba, Costa Rica, CATIE. 50 p. (Serie técnica/Informe técnico n 354). ISBN 978-9977-57-434-9.

Nabuurs GJ, Masera O, Andrasko K, Benitez-Ponce P, Boer R, Dutschke M, Elsiddig E, FordRobertson J, Frumhoff P, Karjalainen T, Krankina O, Kurz WA, Matsumoto M, Oyhantcabal W, Ravindranath NH, Sanz Sanchez MJ, Zhang X (2007) Forestry. In Climate Change 2007: Mitigation. Contribution of Working Group III to the Fourth Assessment Report of the Intergovernmental Panel on Climate Change [B Metz, OR 
Davidson, PR Bosch, R Dave, LA Meyer (eds)], Cambridge University Press, Cambridge, United Kingdom and New York, NY, USA.

Návar J (2009) Allometric equations for tree species and carbon stocks for forests of northwestern Mexico. For. Ecol. Manage. 257: 427-434.

Paquette A, Messier C (2010) The role of plantations in managing the world's forests in the Anthropocene. Front. Ecol. Environ. 8 (1): 27-34.

Petit B, Montagnini F (2004) Growth equations and rotation ages of ten native tree species in mixed and pure plantations in the humid neotropics. For. Ecol. Manage. 199: 243-257.

Pérez D, Kanninen M (2002) Wood specific gravity and aboveground biomass of Bombacopsis quinata plantations in Costa Rica. For. Ecol. Manage. 165: 1-9.

Pérez D, Kanninen M (2003) Aboveground biomass of Tectona grandis plantations in Costa Rica. J. Trop. For. Sci. 15: 199-213.

Piotto D, Craven D, Montagnini F, Alice F (2010) Silvicultural and economic aspects of pure and mixed native tree species plantations on degraded pasturelands in humid Costa Rica. New Forests 39: 369-385. (Also Published online, DOI 10.1007/s11056-009-9177-0).

Powers JS, Veldkamp E (2005) Regional variation in soil carbon and $\delta^{13} \mathrm{C}$ in forests and pastures of northeastern Costa Rica. Biogeochemistry 72:315-336.

Prodan M, Peters R, Cox F, Real P (1997) Mensura forestal. Serie de investigación y evaluación en desarrollo sostenible. San José, Costa Rica, IICA, GTZ. 561 p.

Redondo A and Montagnini F (2006) Growth, productivity, biomass, and carbon sequestration of pure and mixed native tree plantations in the Atlantic lowlands of Costa Rica. For. Ecol. Manage. 232: 168-178. 
Redondo A (2007) Growth, carbon sequestration, and management of native tree plantations in humid regions of Costa Rica. New Forests 34: 253-268.

Rhoades CC, Eckert GE, Coleman DC (2000) Soil carbon differences among forest, agriculture, and secondary vegetation in lower montane Ecuador. Ecol. Appl. 10:497-505.

Russell AE, Raich JW, Valverde OJ, Fisher RF (2007) Tree Species Effects on Soil Properties in Experimental Plantations in Tropical Moist Forest. Soil Sci. Soc. Am. J. 71(4):13891397.

Salas C (2002) Ajuste y validación de ecuaciones de volumen para un relicto del bosque de Roble-Laurel-Lingue. Bosque 23(2): 81-92.

Sarmiento G, Pinillos M, Garay I (2005) Biomass Variability in Tropical American Lowland Rainforests. ECOTROPICOS 18(1):1-20.

Schedlbauer J, Kavanagh K (2008) Soil carbon dynamics in a chronosequence of secondary forests in northeastern Costa Rica. For. Ecol. Manage. 255: 1326-1335.

Schöning I, Totsche KU, Kögel-Knabner I (2006) Small scale spatial variability of organic carbon stocks in litter and solum of a forested Luvisol. Geoderma 136: 631-642

Segura M, Kanninen M, Alfaro M, Campos JJ (2000) Almacenamiento y fijación de carbono en bosques de bajura de la zona Atlántica de Costa Rica. Revista Forestal Centroamericana 30: $23-28$.

Segura M, Kanninen M (2002) Inventario para estimar carbono en ecosistemas forestales. In Inventarios forestales para bosques latifoliados en América Central. Orozco L., C. Brumer (eds.). Turrialba, Costa Rica. CATIE. p. 173-212. (Serie Técnica. Manual Técnico No. 50). 
Segura M, Andrade H (2008) ¿Cómo hacerlo? ¿Cómo construir modelos alométricos de volumen, biomasa o carbono de especies leñosas perennes? Agroforestería de las Américas 46: 89-96.

Singh SK, Singh AK, Sharma BK, Tarafdar JC (2007) Carbon stock and organic carbon dynamics in soils of Rajasthan, India. J. Arid Environ. 68: 408-421.

Solís M, Moya R (2004a) Hyeronima alchorneoides en Costa Rica. San José, Costa Rica, FONAFIFO - Ministerio de Energía y Ambiente de Costa Rica. 98 p. http://www.fonafifo.com/text_files/proyectos/ManualHieronyma.pdf

Solís M, Moya R (2004b) Vochysia guatemalensis en Costa Rica. San José, Costa Rica, FONAFIFO - Ministerio de Energía y Ambiente de Costa Rica. 100 p. http://www.fonafifo.com/text_files/proyectos/ManualVochysia.pdf

Soliz B (1998) Valoración económica del almacenamiento y fijación de carbono en un bosque subhúmedo estacional de Santa Cruz, Bolivia. Tesis Mag. Sc. Turrialba, Costa Rica. CATIE. 113 p.

Sombroek WG, Nachtergaele FO, Hebel A (1993) Amounts, dynamics and sequestering of carbon in tropical and subtropical soils. Ambio 22:417-426.

Somogyi Z, Teobaldelli M, Federici S, Matteucci G, Pagliari V, Grassi G, Seufert G (2008)

Allometric biomass and carbon factors database. iForest 1:107-113. http://www.sisef.it/iforest/

Subak S (2000) Forest protection and reforestation in Costa Rica: Evaluation of a clean development mechanism prototype. Environ. Manage. 26(3):283-297. 
Tan Z, Liu S, Tieszen L, Tachie-Obeng E (2009) Simulated dynamics of carbon stocks driven by changes in land use, management and climate in a tropical moist ecosystem of Ghana. Agric., Ecosyst. Environ. 130(3-4): 171-176.

Tschakert P, Coomes OT, Potvin C (2007) Indigenous livelihoods, slash-and-burn agriculture, and carbon stocks in Eastern Panama. Ecol. Econ. 60: 807 - 820.

Turner J, Lambert MJ, Johnson DW (2005) Experience with patterns of change in soil carbon resulting from forest plantation establishment in eastern Australia. For. Ecol. Manage. 220: 259-269.

UNFCCC (2010) Report on the informal meeting of experts on enhancing coordination of capacity-building activities in relation to using the Intergovernmental Panel on Climate Change guidance and guidelines as a basis for estimating forest-related greenhouse gas emissions and removals, forest carbon stocks and forest area changes. Bonn, Germany, 25-26 May 2010. http://unfccc.int/files/methods_science/redd/application/pdf/expert_meeting_report.pdf van Noordwijk M, Rahayu S, Hairiah K, Wulan YC, Farida A, Verbist B (2002) Carbon stock assessment for a forest-to-coffee conversion landscape in Sumber-Jaya (Lampung, Indonesia): from allometric equations to land use change analysis. Science in China. 45(Series C): 75-86.

Veldkamp E, Becker A, Schwendenmann L, Clark D, Schulte - Bisping H (2003) Substantial labile carbon stocks and microbial activity in deeply weathered soils below a tropical wet forest. Glob. Change Biol. 9:1171-1184. 
Table 1a. Biomass and carbon accumulation $\left(\mathrm{Mg} \mathrm{ha}^{-1}\right)$ in $V$. guatemalensis single species forestry plantations. Average \pm SD.

\begin{tabular}{|c|c|c|c|c|c|c|c|c|c|c|}
\hline \multirow{2}{*}{$\begin{array}{l}\text { Pool } \\
\end{array}$} & \multirow[b]{2}{*}{ Components } & \multicolumn{9}{|c|}{ Age (years) } \\
\hline & & $\mathbf{0}$ & 0.7 & 3.2 & 5 & 7 & 9 & 12 & 14 & 16 \\
\hline \multirow[t]{5}{*}{ Tree B } & Leaves & & $0.2 \pm 0.2$ & $3.5 \pm 4.0$ & $5.2 \pm 0.4$ & $4.5 \pm 2.8$ & $3.0 \pm 1.4$ & $6.4 \pm 2.5$ & $3.8 \pm 1.8$ & $5.1 \pm 0.0$ \\
\hline & Branches & & $0.1 \pm 0.1$ & $5.3 \pm 7.0$ & $8.7 \pm 2.7$ & $12.2 \pm 7.5$ & $12.4 \pm 8.7$ & $39.9 \pm 29.7$ & $13.4 \pm 8.4$ & $8.8 \pm 0.0$ \\
\hline & Stems & & $0.5 \pm 0.1$ & $8.9 \pm 11.8$ & $40.4 \pm 7.6$ & $60.2 \pm 22.6$ & $83.0 \pm 30.0$ & $113.6 \pm 32.7$ & $109.7 \pm 69.0$ & $145.5 \pm 0.0$ \\
\hline & Roots & & $0.1 \pm 0.0$ & $4.8 \pm 6.0$ & $13.6 \pm 2.0$ & $21.9 \pm 18.9$ & $34.2 \pm 16.8$ & $33.5 \pm 21.4$ & $31.9 \pm 19.6$ & $52.6 \pm 0.0$ \\
\hline & Total tree & & $0.5 \pm 0.35$ & $19.2 \pm 27.4$ & $68.6 \pm 8.0$ & $98.8 \pm 39.1$ & $132.5 \pm 50.7$ & $193.3 \pm 81.2$ & $157.8 \pm 93.9$ & $212.1 \pm 0,0$ \\
\hline \multirow[t]{5}{*}{ Tree C } & Leaves & & $0.1 \pm 0.1$ & $2.2 \pm 3.3$ & $2.2 \pm 0.3$ & $1.9 \pm 1.2$ & $1.3 \pm 0.5$ & $2.7 \pm 1.1$ & $1.5 \pm 0.7$ & $2.0 \pm 0.0$ \\
\hline & Branches & & $0.0 \pm 0.0$ & $3.1 \pm 4.2$ & $3.9 \pm 1.3$ & $5.8 \pm 3.4$ & $5.8 \pm 4.0$ & $18.6 \pm 13.8$ & $5.6 \pm 3.9$ & $3.4 \pm 0.0$ \\
\hline & Stems & & $0.1 \pm 0.0$ & $5.0 \pm 6.2$ & $20.0 \pm 1.2$ & $28.8 \pm 10.8$ & $40.2 \pm 14.4$ & $54.8 \pm 15.8$ & $49.3 \pm 30.5$ & $64.2 \pm 0.0$ \\
\hline & Roots & & $0.0 \pm 0.0$ & $2.9 \pm 3.8$ & $6.3 \pm 0.9$ & $10.2 \pm 7.7$ & $17.0 \pm 8.0$ & $16.4 \pm 10.4$ & $15.3 \pm 9.6$ & $25.6 \pm 0.0$ \\
\hline & Total tree & & $0.24 \pm 0.2$ & $9.9 \pm 13.3$ & $32.3 \pm 1.3$ & $46.7 \pm 16.9$ & $63.9 \pm 24.1$ & $92.4 \pm 38.7$ & $71.7 \pm 42.3$ & $95.2 \pm 0.0$ \\
\hline Herbaceous C & & $1.1 \pm 0.1$ & $2.5 \pm 1.0$ & $0.3 \pm 0.2$ & $0.6 \pm 0.4$ & $0.6 \pm 0.6$ & $0.7 \pm 0.5$ & $0.6 \pm 0.8$ & $3.8 \pm 0.0$ & $0.2 \pm 0.0$ \\
\hline \multirow[t]{2}{*}{ Necromass C } & Fine & $0.0 \pm 0.0$ & $0.0 \pm 0.0$ & $1.9 \pm 1.4$ & $2.1 \pm 1.3$ & $2.0 \pm 1.1$ & $1.6 \pm 0.7$ & $2.7 \pm 1.1$ & $2.7 \pm 0.0$ & $0.6 \pm 0.0$ \\
\hline & Large & $0.0 \pm 0.0$ & $0.0 \pm 0.0$ & $0.0 \pm 0.0$ & $1.4 \pm 0.1$ & $3.1 \pm 2.4$ & $12.1 \pm 21.7$ & $2.4 \pm 0.9$ & $3.4 \pm 0.0$ & $1.2 \pm 0.0$ \\
\hline
\end{tabular}




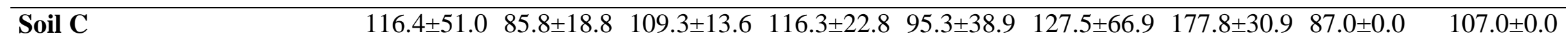


Table 1b. Biomass and carbon accumulation $\left(\mathrm{Mg} \mathrm{ha}^{-1}\right)$ in $H$. alchorneoides single species forestry plantations. Average \pm SD.

\begin{tabular}{|c|c|c|c|c|c|c|c|c|c|c|}
\hline \multirow[b]{2}{*}{ Pool } & \multirow[b]{2}{*}{ Components } & \multicolumn{9}{|c|}{ Age (years) } \\
\hline & & $\mathbf{0}$ & 0.8 & 3.2 & 5 & 7.2 & 9.06 & 12 & 14.7 & 16 \\
\hline \multirow[t]{5}{*}{ Tree B } & Leaves & & $0.3 \pm 0.3$ & $5.6 \pm 3.2$ & $1.7 \pm 1.7$ & $3.6 \pm 0.7$ & $3.8 \pm 1.7$ & $2.9 \pm 0.8$ & $3.7 \pm 1.4$ & $3.0 \pm 0.5$ \\
\hline & Branches & & $0.1 \pm 0.1$ & $10.6 \pm 8.4$ & $2.3 \pm 1.8$ & $12.0 \pm 10.1$ & $23.7 \pm 13.3$ & $25.9 \pm 7.3$ & $13.8 \pm 8.0$ & $19.6 \pm 4.7$ \\
\hline & Stems & & $0.5 \pm 0.6$ & $18.0 \pm 13.3$ & $7.2 \pm 5.4$ & $32.7 \pm 13.0$ & $55.8 \pm 33.2$ & $66.5 \pm 12.6$ & $68.5 \pm 28.8$ & $115.3 \pm 22.8$ \\
\hline & Roots & & $0.2 \pm 0.3$ & $10.6 \pm 7.6$ & $3.8 \pm 4.2$ & $13.0 \pm 8.7$ & $27.7 \pm 11.7$ & $29.9 \pm 5.3$ & $29.3 \pm 9.1$ & $9.6 \pm 19.1$ \\
\hline & Total tree & & $1.2 \pm 1.3$ & $44.7 \pm 32.3$ & $14.9 \pm 12.7$ & $61.3 \pm 28.6$ & 111.1 \pm 51.5 & $125.1 \pm 13.9$ & $115.3 \pm 40.7$ & $146.5 \pm 23.5$ \\
\hline \multirow[t]{5}{*}{ Tree C } & Leaves & & $0.1 \pm 0.1$ & $2.6 \pm 1.4$ & $0.7 \pm 0.7$ & $1.8 \pm 0.3$ & $1.7 \pm 0.8$ & $1.3 \pm 0.3$ & $1.7 \pm 0.7$ & $1.4 \pm 0.2$ \\
\hline & Branches & & $0.1 \pm 0.1$ & $5.1 \pm 4.0$ & $1.2 \pm 0.9$ & $5.7 \pm 4.8$ & $11.8 \pm 6.8$ & $12.5 \pm 3.5$ & $5.9 \pm 4.3$ & $8.7 \pm 1.8$ \\
\hline & Stems & & $0.3 \pm 0.3$ & $8.9 \pm 6.6$ & $3.7 \pm 2.5$ & $14.5 \pm 6.2$ & $28.0 \pm 16.7$ & $33.1 \pm 6.2$ & $34.1 \pm 14.3$ & $53.4 \pm 8.8$ \\
\hline & Roots & & $0.1 \pm 0.2$ & $5.2 \pm 3.8$ & $1.7 \pm 1.7$ & $7.0 \pm 4.3$ & $13.3 \pm 5.6$ & $14.6 \pm 2.6$ & $14.3 \pm 4.5$ & $4.7 \pm 9.4$ \\
\hline & Total tree & & $0.6 \pm 0.6$ & $21.8 \pm 15.7$ & $7.4 \pm 5.6$ & $29.0 \pm 14.7$ & $54.8 \pm 25.7$ & $61.6 \pm 6.9$ & $56.1 \pm 19.1$ & $68.3 \pm 11.0$ \\
\hline Herbaceous C & & $0.91 \pm 0.3$ & $1.4 \pm 0.6$ & $0.7 \pm 0.6$ & $1.0 \pm 0.4$ & $1.0 \pm 0.5$ & $0.6 \pm 0.4$ & $0.2 \pm 0.1$ & $0.6 \pm 0.4$ & $0.1 \pm 0.0$ \\
\hline \multirow[t]{2}{*}{ Necromass C } & Fine & $0.0 \pm 0.0$ & $0.2 \pm 0.7$ & $3.4 \pm 2.6$ & $1.9 \pm 2.0$ & $2.2 \pm 1.0$ & $2.1 \pm 0.7$ & $5.1 \pm 2.0$ & $3.3 \pm 2.3$ & $1.2 \pm 0.0$ \\
\hline & Large & $0.0 \pm 0.0$ & $0.0 \pm 0.0$ & $0.2 \pm 0.2$ & $0.5 \pm 1.2$ & $1.6 \pm 1.4$ & $4.9 \pm 7.2$ & $1.6 \pm 0.9$ & $2.3 \pm 4.1$ & $0.9 \pm 0.0$ \\
\hline
\end{tabular}




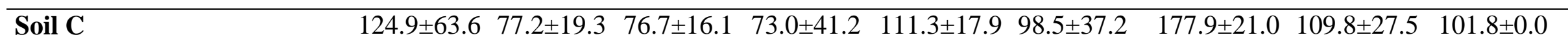


Table 2. Carbon fraction (\%) in the biomass of forest tree plantations with ages between 0.5 and 16 years.

\begin{tabular}{|c|c|c|c|c|c|c|c|c|}
\hline Species & Statistics & Stem & Branches & Leaves & Roots & $\begin{array}{c}\text { Herbaceous } \\
\text { vegetation }\end{array}$ & $\begin{array}{c}\text { Large } \\
\text { necromass }\end{array}$ & $\begin{array}{c}\text { Fine } \\
\text { necromass }\end{array}$ \\
\hline \multirow[t]{3}{*}{ V. guatemalensis } & $X$ & 48.11 & 46.46 & 42.95 & 48.63 & 44.64 & 48.51 & 38.50 \\
\hline & $S D$ & 4.11 & 4.73 & 3.85 & 3.68 & 3.26 & 4.57 & 2.97 \\
\hline & $n$ & 59 & 59 & 59 & 59 & 68 & 41 & 44 \\
\hline \multirow[t]{3}{*}{ H. alchorneoides } & $X$ & 49.67 & 47.65 & 45.94 & 49.24 & 43.99 & 46.98 & 42.79 \\
\hline & $S D$ & 3.77 & 7.99 & 4.74 & 3.39 & 21.25 & 9.9 & 9.11 \\
\hline & $n$ & 61 & 60 & 61 & 58 & 72 & 45 & 51 \\
\hline
\end{tabular}


Table 3. Selected model for the estimation of total biomass and carbon in the biomass $\left(\mathrm{Mg} \mathrm{ha}^{-1}\right)$ in forestry plantations of $V$. guatemalensis and H. alchorneoides. All models with $\mathrm{P}<0.0001$.

\begin{tabular}{|c|c|c|c|c|c|}
\hline Species & Selected model & $R^{2}$ aj $(\%)$ & SEE & IF & $n$ \\
\hline \multirow{3}{*}{ V. guatemalensis } & $\log (\mathrm{BT})=1.32107+0.678129 * \sqrt{\mathrm{G}}$ & 95.3 & 0.381 & 1.28 & 64 \\
\hline & $\mathrm{Cba}=(0.146365+1.38023 * \sqrt{ } \mathrm{G})^{\wedge} 2$ & 96.6 & 0.657 & & 56 \\
\hline & $\log (\mathrm{CBT})=0.540135+0.68418 * \sqrt{\mathrm{G}}$ & 94.6 & 0.413 & 0.73 & 64 \\
\hline \multirow{3}{*}{ H. alchorneoides } & $\mathrm{BT}=\exp (0.891012+1.08278 * \sqrt{\mathrm{G}})$ & 96.4 & 0.333 & & 65 \\
\hline & $\log (\mathrm{Cba})=-1.42086+1.51576 * \sqrt{\mathrm{G}}$ & 96.0 & 0.406 & 1.27 & 51 \\
\hline & $\mathrm{CBT}=\exp (0.0934072+1.11676 * \sqrt{\mathrm{G}})$ & 96.4 & 0.345 & & 65 \\
\hline \multicolumn{6}{|c|}{$G$ (basal area in $\left.\mathrm{m}^{2} \mathrm{ha}^{-1}\right), B T$ (total biomass in $\left.\mathrm{Mg} \mathrm{ha}^{-1}\right), C b a$ (carbon in tree biomass $\mathrm{Mg} \mathrm{ha}^{-1}$ ), } \\
\hline \multicolumn{6}{|c|}{ CBT (carbon in total biomass in $\mathrm{Mg} \mathrm{ha}^{-1}$ ), $R^{2}$ aj (adjusted coefficient of determination), SEE } \\
\hline
\end{tabular}

